\title{
Digital risk management
}

\author{
Natalya Sirotkina ${ }^{1, *}$, Elena Shkarupeta $^{1}$, Victoria Kruglyakova ${ }^{1}$, and Anna Batova ${ }^{1}$ \\ ${ }^{1}$ Voronezh State Technical University, Moscow Avenue, 14, Voronezh, 394026, Russia
}

\begin{abstract}
Based on the latest statistics, an analysis of indicators, indices and sub-indices wasmade, showing the level of development of information and communication technologies in the world, and a comparative description of Russia with the leading countries was carried out. Using methods of analysis, comparison, induction and decomposition, it is possible to determine which areas of the Russian digital economy are successfully implemented and competitive, and which suffer and need support. The process of global digitalization has been started. In order to reach a higher level of development, it is necessary to increase the share of activities in the field of information in relation to GDP.
\end{abstract}

\section{Introduction}

The origins of the digital economy lie at the time of the advent of the Internet, but this term appeared more consciously in 2017. Nowadays, the digital economy is actively developing in Russia and in the world, but not everywhere uniformly. The creation of technological platforms, applied Internet services, analytical groups, information systems of public authorities, the number of subscribers of mobile cellular and Internet communications, all this characterizes the level of development of the digital economy in the country. The digital economy is an economic activity in which the key factor in production is digital data, the processing of large volumes and the use of the analysis results of which, compared with traditional forms of management, can significantly increase the efficiency of various types of production, technologies, equipment, storage, sales delivery of goods and services [1].

The digital economy includes those areas of the economy in which the added value of market things is created thanks to information technologies [2].

It is worth noting that the term "digital economy" did not appear immediately. In 2015, at a forum with President V.V. Putin, when started to consider the term of Internet Plus, the question of its name was discussed. There were options: new economy, smart economy, digital economy. The last term was rejected at the beginning, but after a while they came to it, and in 2017 the Autonomous Non-Profit Organization "Digital Economy" appeared.

\footnotetext{
${ }^{*}$ Corresponding author: 9056591561@mail.ru
} 


\section{Experimental}

The digital economy is everywhere: buying tickets for a concert or plane, transfers from card to card to a relative or friend, paying with a smartphone at the grocery store. Thanks to digital solutions, our life has been greatly simplified, and its rhythm has accelerated, because now most of the problems can be solved in a couple of clicks, without leaving home. Let's consider the impact of digitalization. Positive factors are [3]:

1. Simplification of the process of financial transactions, a gradual transition to electronic money.

2. Simplification of workflow, due to the transition to electronic documents (work record books, sick leave), and as a result, reduction of bureaucracy.

3. Minimization of time spent on financial transactions.

4. Reducing the costs associated with finding information, transaction costs, negotiating, and promoting goods and services.

5. "Robotization" of many professions, reducing errors and the influence of the "human factor" [4].

6. Increase in labor productivity thanks to modern automated systems.

7. Reducing corruption, including due to online government services, the federal tax service.

8. Improving the quality of life, the level of medicine and infrastructure [5].

9. The emergence of new business models with greater profitability and competitiveness. In addition to the undeniable positive characteristics, the digital economy has the following risks and threats:

1. The danger to national security.

2. Digital fraud (hacking of accounts on social media networks, extortion of funds through messages, debiting of funds from cards).

3. The presence of a shadow digital economy (payment of products and services per card to an individual without paying taxes).

4. Strengthening the stratification of society in relation to the development of scientific and technological progress, widening the gap with third world countries.

5. The loss of many professions, job cuts.

6. Increase in unemployment.

7. Retraining of personnel, training people throughout their lives [6].

8. The ability for attackers to use the personal data of a huge number of people for personal gain.

9. Decrease in privacy.

10. The backlog of the regulatory framework from the growth rate of the digital economy [7].

It is worth noting that many of the negative aspects of the digital economy can and should become growth areas for it. So, for example, the elimination of those jobs that will be automated leads to retraining of personnel, a change in specialties, and the emergence of new, more highly qualified personnel.

The process of global digitalization has been started, and the task of the Russian Federation is not to be among those catching up, so as not to lose the possibility of innovative development, but to strive for leadership and increase both the competitiveness of Russian companies and the entire Russian economy on the global stage. Using the methods of analysis, comparison, induction and decomposition, it is possible to determine which areas of the Russian digital economy are successfully implemented and competitive, and which suffer and need support. However, a comparative characteristic is not enough to 
reach a higher level of development; it is necessary to increase the share of information activities in relation to GDP. According to statistics, internal costs for the development of the digital economy are $3.6 \%$ of GDP, of which $1.5 \%$ - the business sector, $0.4 \%$ - the public sector, $0.03 \%$ - the higher education sector, $0.01 \%$ - the non-profit sector, $1.3 \%$ - the household sector, $0.4 \%$ - the costs of organizations and households for the consumption of products of the content and media sector [8].

\section{Evaluation}

In 2017, Russia holds the following positions in the international ratings of the development of the digital economy: 45th place according to the ICT development index, 32 th place according to the e-government development index, 26th place according to the global cybersecurity index.

It is worth noting that despite the far from leading positions, the growth rate of information and communication technologies is quite high, and Russia is approaching the countries with the highest value of this index. The schedule for the development of information and communication technologies in Russia in the dynamics of 2008-2017 compared with other countries is presented in Figure 1 [8]. The most advanced countries for this index are: Iceland, Republic of Korea, Switzerland, Denmark, United Kingdom, Hong Kong (China), Netherlands, Norway, Luxemburg, and Japan.

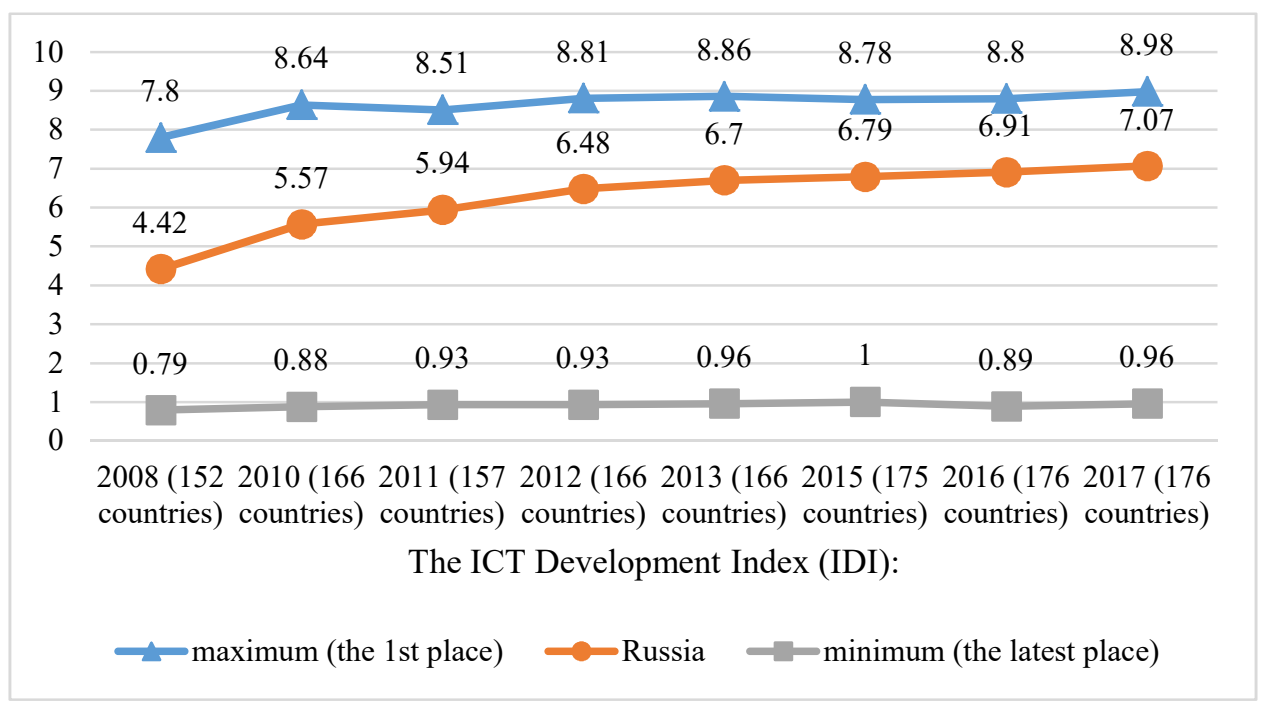

Fig. 1. The graph of the development of information and communication technologies in Russia in the dynamics of 2008-2017 in comparison with other countries.

However, it is difficult to talk about the level of development of information and communication technologies throughout the country, when the difference between the capital and some regions is so great [9]. For example, in 2018, Moscow ranks first in the world in the local online services index, gaining a value of 55 out of 60 . This index includes the following groups of indicators: technological, provision of content, provision of services, participation and involvement of citizens. The city of Cape Town (South Africa) is in second place, Tallinn (Estonia) in third, London (Great Britain) in fourth, and Paris (France) in fifth. The obtained statistics tell us that in Russia, namely in Moscow, there is knowledge and resources in order to occupy a leading position in the world. However, 
modern communication technologies need to be distributed throughout the country to cover even larger areas with communication networks and Internet [10].

There is also another international index of the digital economy and society, the dynamics of the values of which are presented in Figure 2 [8].

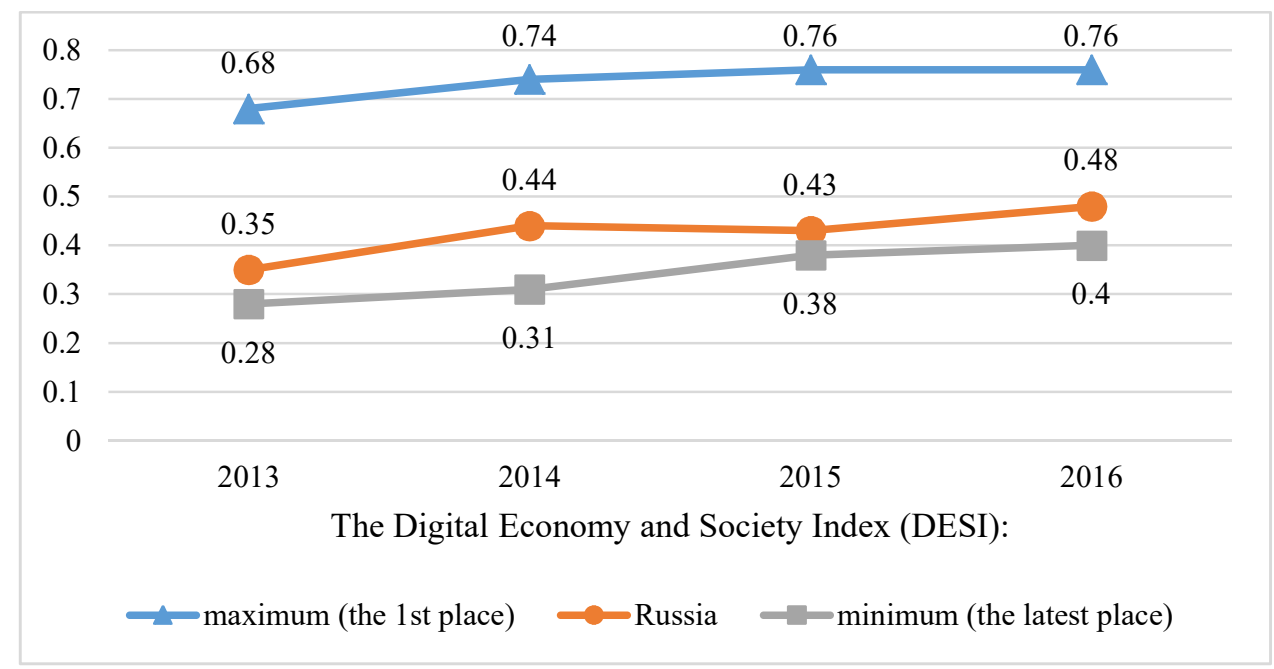

Fig. 2. The graph of the development of the value of the International Digital Economy and Society Index in Russia in the dynamics of 2013-2016 in comparison with other countries.

According to the International Digital Economy and Society Index, in 2016, Russia holds 39th place with an index value of 0.48. A smooth increase in the value of this indicator is occurring, but it is insufficient and has not yet caught up with the leading countries such as Denmark, the Republic of Korea, Finland, the Netherlands, Great Britain, Iceland, Norway, Sweden, Luxembourg with a maximum index value of 0.76 [11]. The same quantitative value with Russia is occupied by the following countries: Bulgaria, Cyprus, Greece. The international digital economy and society index includes the following sub-indices: connectivity, human capital, Internet use, digital technology integration, digital public services [12]. The strongest side of Russia is the sphere associated with human capital, and the integration of digital technologies is still at a low level and is the weakest spot in the Russian digital economy [8].

In order to understand what separates Russia from the leading countries, it is necessary to compare the indicators of information and communication technologies in the structure of the global innovation index. In 2018, Switzerland holds the first place in the ranking according to this indicator, while Russia is on the 46th line [13]. We will analyze five subindices: human capital and science, infrastructure, business development, development of technologies and the knowledge economy, development of creative activity (table 1) [8]. The ranking was attended by 126 countries. The complete list of countries for which the rating is carried out is presented in the analytical report of the consortium of the Cornell University, the INSEAD Business School and the World Intellectual Property Organization (WIPO) "The Global Innovation Index 2018. Energizing the World with Innovation" [14]. 
Table 1. Indicators of information and communication technologies in the structure of the global innovation index for 2018.

\begin{tabular}{|c|c|c|c|c|c|}
\hline & \multicolumn{2}{|l|}{ Russia } & \multicolumn{2}{|c|}{$\begin{array}{l}\text { Leading country: } \\
\text { Switzerland }\end{array}$} \\
\hline & & $\begin{array}{l}\text { Place in the rating } \\
\text { by the } \\
\text { corresponding } \\
\text { indicator }\end{array}$ & Value & $\begin{array}{l}\text { Place in the rating by } \\
\text { the corresponding } \\
\text { indicator }\end{array}$ & Value \\
\hline \multicolumn{2}{|c|}{ Global Innovation Index } & 46 & 37.9 & 1 & 68.4 \\
\hline Subindex 1 & $\begin{array}{l}\text { Human capital } \\
\text { and science }\end{array}$ & 22 & 48.4 & 5 & 64.0 \\
\hline Block 1.1 & Higher education & 19 & 49.1 & 16 & 54.8 \\
\hline Block 1.2 & $\begin{array}{l}\text { Graduates of } \\
\text { scientific and } \\
\text { engineering } \\
\text { specialties }\end{array}$ & 15 & 29.0 & 32 & 24.4 \\
\hline Subindex 2 & Infrastructure & 63 & 45.2 & 8 & 65.3 \\
\hline Block 2.1 & $\begin{array}{l}\text { Information and } \\
\text { Communication } \\
\text { Technology }\end{array}$ & 37 & 70.3 & 30 & 73.8 \\
\hline Block 2.2 & Access to ICT & 45 & 72.3 & 7 & 88.5 \\
\hline Block 2.3 & Use of ICT & 46 & 61.3 & 2 & 88.8 \\
\hline Block 2.4 & $\begin{array}{l}\text { Online } \\
\text { government } \\
\text { services index }\end{array}$ & 37 & 73.2 & 64 & 60.1 \\
\hline Block 2.5 & $\begin{array}{l}\text { Index of } \\
\text { electronic } \\
\text { participation of } \\
\text { the population in } \\
\text { government } \\
\text { decision-making }\end{array}$ & 32 & 74.6 & 70 & 57.6 \\
\hline Subindex 3 & $\begin{array}{l}\text { Business } \\
\text { development }\end{array}$ & 33 & 39.9 & 4 & 62.6 \\
\hline Block 3.1 & $\begin{array}{l}\text { Mastering } \\
\text { knowledge }\end{array}$ & 35 & 38.1 & 9 & 53.3 \\
\hline Block 3.2 & $\begin{array}{l}\text { Import of ICT } \\
\text { services }\end{array}$ & 28 & 1.8 & 5 & 3.7 \\
\hline Subindex 4 & $\begin{array}{l}\text { Technology and } \\
\text { knowledge } \\
\text { economy } \\
\text { development }\end{array}$ & 47 & 28.9 & 1 & 74.9 \\
\hline Block 4.1 & $\begin{array}{l}\text { Impact of } \\
\text { knowledge }\end{array}$ & 80 & 32.5 & 4 & 57.9 \\
\hline Block 4.2 & Software costs & 48 & 0.3 & 3 & 0.8 \\
\hline Block 4.3 & $\begin{array}{l}\text { Knowledge } \\
\text { dissemination }\end{array}$ & 51 & 21.5 & 3 & 76.9 \\
\hline Block 4.4 & $\begin{array}{l}\text { Export of ICT } \\
\text { services }\end{array}$ & 72 & 1.3 & 11 & 14.1 \\
\hline Subindex 5 & $\begin{array}{l}\text { Creative activity } \\
\text { development }\end{array}$ & 72 & 26.9 & 1 & 59.4 \\
\hline Block 5.1 & Intangible assets & 71 & 39.0 & 8 & 62.0 \\
\hline Block 5.2 & $\begin{array}{l}\text { ICT and business } \\
\text { model building }\end{array}$ & 94 & 52.7 & 1 & 86.2 \\
\hline Block 5.3 & $\begin{array}{l}\text { Number of } \\
\text { country domains }\end{array}$ & 33 & 14.6 & 1 & 100.0 \\
\hline Block 5.4 & $\begin{array}{l}\text { Mobile app } \\
\text { development }\end{array}$ & 24 & 33.7 & 13 & 42.0 \\
\hline
\end{tabular}

Based on this table, we can conclude that according to the subindex "Human capital and science", Russia holds a good position (22nd place) relative to its overall place (46), but still lags behind Switzerland, which holds 5 - th place according to this indicator. The values 
of the blocks included in the subindex confirm the high level of Russian education, since Russia occupies the 19th place in higher education, and Switzerland - the 16th. In terms of the number of graduates of scientific and engineering specialties, Russia occupies the 15th place and even surpasses Switzerland, which occupies the 32nd position. It is worth noting here that the indicator was influenced by the quality of Russian technical education and its priority in the Russian economy, and also the number of higher education institutions in Russia and the size of the country itself, many times exceeding the size of Switzerland.

Now let's move on to the second subindex - infrastructure. Russia here shows results only for 63rd place. There is a big lag in the field of information and communication technologies (37th place), in the field of access and use of ICTs (45th and 46th place). However, in terms of the index of online public services (37th place) and the index of electronic participation of the population in government decision-making (32nd place), Russia is ahead of Switzerland, showing disappointing results (64th and 70th places, respectively).

In terms of business development, Russia occupies the 33rd position against the 4th place of Switzerland. The categories of knowledge development and import of services are in comparable positions (35th and 28th place). In this area, Russia should also adopt the experience of Switzerland to improve its own level.

The development of technologies and the knowledge economy is the leading field for Switzerland (1st place), but Russia should significantly increase its capabilities in these areas: the impact of knowledge (80th place) and software costs (48th place).

\section{Conclusions}

A steady increase in access to the Internet throughout the world suggests that the digital era has long come, and Russia's task is to keep up with the times and strive to become one of the leaders [15]. It is worth noting Russia's good position regarding global data in such areas as practical skills in using information and communication technologies, cybersecurity, human capital, the development of e-government, especially online government services. It is necessary to continue to develop strengths and reach the top positions in global ratings. However, areas in which Russia is far behind the leaders cannot be forgotten. It is necessary to try learning from the experience of leading countries in this area.

\section{References}

1. N.V. Sirotkina, Advances in Intelligent Systems and Computing 622, 597-602 (2018)

2. T. Tolstykh, D. Savon, A. Safronov, E. Shkarupeta, T. Ivanochkina, Proceedings of the 32nd International Business Information Management Association Conference, IBIMA 2018 - Vision 2020: Sustainable Economic Development and Application of Innovation Management from Regional expansion to Global Growth, 7723-7729 (2018)

3. V.G. Khalin, G.V. Chernova, Management consulting 10, 46-63 (2018)

4. H. Millwater, J. Ocampo, N. Crosby, Engineering Fracture Mechanics 221 (2019) https://doi.org/10.1016/j.engfracmech.2019.106674

5. A. Aziz, M. Tajuddin, M. Adzman, M. Mohammed, M. Ramli, Energy 191 (2020) https://doi.org/10.1016/j.energy.2019.116591

6. R. Jean, D. Kim, E. Cavusgil, Journal of World Business 55(1) (2020) https://doi.org/10.1016/j.jwb.2019.101021 
7. A. Dhoke, R. Sharma, T. Saha, Energy 194, 197-208 (2019) https://doi.org/10.1016/j.solener.2019.10.052

8. G.I. Abdrakhmanova, K.O. Vishnevsky, L.M. Gokhberg et al., Indicators of the digital economy: 2019: statistical compilation (HSE, Moscow, 2019)

9. I. Rodríguez-de-Dios, J. Oosten, J. Igartua, Computers in Human Behavior 82, 186-198 (2018) https://doi.org/10.1016/j.chb.2018.01.012

10. A.S. Abdelrazik, F.A. Al-Sulaiman, R. Saidur, Energy Conversion and Management 205 (2020) https://doi.org/10.1016/j.enconman.2019.112449

11. O. Raimon, S. Numan, Energy Reports 6, 173-208 (2020) https://doi.org/10.1016/j.egyr.2019.12.010

12. N. Elminshawy, M. Ghandour, H. Gad, D. El-Damhogi, K. El-Nahhas, M. Addas, Geothermics 82, 7-15 (2019) https://doi.org/10.1016/j.geothermics.2019.05.012

13. H. Ali, Solar Energy https://doi.org/10.1016/j.solener.2019.11.075

197, 163-198

14. Z. Li, J. Ji, W. Yuan, Z. Song, X. Ren, M. Uddin, K. Luo, X. Zhao, Energy 194 (2020) https://doi.org/10.1016/j.energy.2019.116776

15. J. Taskin, C. Craig, T. Schmidt, G. Shafiullah, M. Calais, T. Urmee, Applied Energy 254 (2019) https://doi.org/10.1016/j.apenergy.2019.113718 